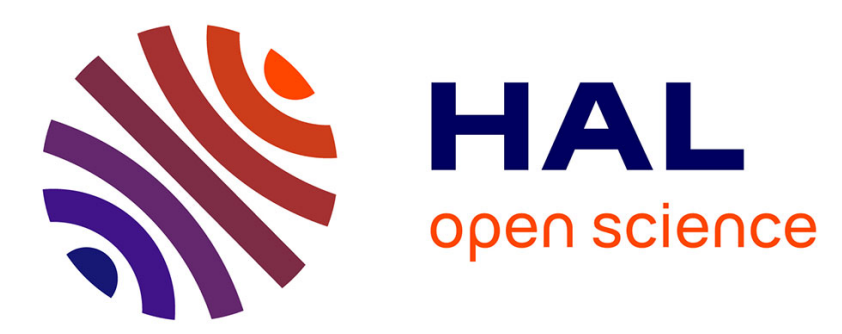

\title{
Working at the boundaries: Middle managerial work as a source of emancipation and alienation
}

\author{
Ricardo Azambuja, Gazi Islam
}

\section{To cite this version:}

Ricardo Azambuja, Gazi Islam. Working at the boundaries: Middle managerial work as a source of emancipation and alienation. Human Relations, 2019, 72 (3), pp.534-564. halshs-01959107

\section{HAL Id: halshs-01959107 https://shs.hal.science/halshs-01959107}

Submitted on 18 Dec 2018

HAL is a multi-disciplinary open access archive for the deposit and dissemination of scientific research documents, whether they are published or not. The documents may come from teaching and research institutions in France or abroad, or from public or private research centers.
L'archive ouverte pluridisciplinaire $\mathbf{H A L}$, est destinée au dépôt et à la diffusion de documents scientifiques de niveau recherche, publiés ou non, émanant des établissements d'enseignement et de recherche français ou étrangers, des laboratoires publics ou privés. 
Running head: MIDDLE MANAGERIAL WORK

Working at the Boundaries:

Middle Managerial Work as a Source of Emancipation and Alienation

Azambuja, R. \& Islam, G. (2018).Working at the boundaries: Middle managerial work as a source of emancipation and alienation. Human Relations, onlinefirst

\begin{abstract}
The current paper examines the experience of middle management through the concept of boundary work, characterized as the work of negotiating between multiple roles at the interstices of organizational groups. Through an ethnographic study of a Brazilian accounting firm, we explore the ambivalent experience of boundary work as characteristic of professional middle managerial workers. Our managers described themselves as proactive and reflexive agents, on the one hand, yet also as lacking autonomy and a sense of belonging, on the other. We examine this tension as a contrast between forces of emancipation (i.e. sense of mastery, autonomy, empowerment and reflexivity) and alienation (i.e. fatigue, lack of selfdetermination, and detachment from their profession and coworkers). We discuss these forces and their implications for managerial work in the light that, in our findings, managers routinely shift between being agential and reflexive mediators - boundary subjects - and interfacing and coordination devices - boundary objects.
\end{abstract}

Key-words: alienation, boundary objects, boundary subjects, Brazil, emancipation, ethnography, experience of work, managerial work, middle managers, politics of everyday life. 


\section{INTRODUCTION}

Middle managerial experience takes place within complex configurations of roles (e.g. Rouleau and Balogun, 2011). By roles, we refer to people's socially constructed positions and performances in a given organization, which may be multiple and conflicting (Ashforth et al., 2000). Where employees work between, adapt to, and cope with competing and contradictory role demands, the resulting complexity impacts their subjective experiences of work and of themselves (Beech, 2011). Such complexity, moreover, particularly characterizes middle managers, who deal on a daily basis with multiple organizational functions, working between ranks and occupying multiple roles (Harding et al., 2014). How such heterogeneity reverberates in the work lives of middle managers has implications for contemporary managerial work situations marked by contradictory and increased work pressure (e.g. Mumby et al., 2017).

The current study reports the results of a multi-site ethnography of middle managers in a Brazilian accounting firm to understand middle managers' boundary work and its ambivalent repercussions for the experiences of middle managerial work. Specifically, tensions ensuing from middle managers' performing with, and adjusting to, multiple actors in their attempts to foster collaboration may give rise to contradictory experiences that are not well understood. We describe the position taken by middle managers as being that of "boundary subjects" (Huzzard et al., 2010) - people who perform the functions of boundary objects - and term their work "boundary work". In performing boundary work, middle managers experience being boundary subjects - that is, agential and reflexive mediators between social positions. Yet, they also experience being used as interfacing and coordination devices for the sake of organizational functioning - that is, being boundary objects (Star and Griesemer, 1989). These contrasting experiences establish ambivalence as a core characteristic of boundary work. 
The literature on middle managers emphasizes that their work takes place at symbolic boundaries, such as those between different logics (e.g. Llewellyn, 2001), distinct hierarchical ranks (e.g. Balogun, 2003), and divergent organizational groups and coalitions (e.g. Raes et al., 2011). By drawing on contradictory sources to construct their precarious and contingent work situations (Down and Reveley, 2009) between elites and workers in organizations and in society at large (Peschanski, 1985), middle managers perform antagonistic roles such as those of leader and bureaucrat (Sveningsson and Alvesson, 2003), controller and controlled, and resister and resisted (Harding et al., 2014). They deal with demands for both emotional engagement and detachment, professionalism and unprofessionalism, and are expected to privilege the interests of both the business and the individuals within it (Clarke et al., 2009). Thus, understanding the contradictions emerging from the work of mediating across various kinds of boundaries is a central task for the literature on middle managers.

Studying middle managers' lived experiences of work is of particular importance given the centrality of middle managers (Ahearne et al., 2014) in both large and mediumsized organizations (Mair and Thurner, 2008). Yet, few studies have provided empirical evidence to specify how middle managers deal subjectively with the challenges they face (Pawlowski and Robey, 2004), nor has there been significant study of managerial work in accounting firms (Korica et al., 2017), our empirical setting.

Most research on individuals performing boundary work between contradictory influences has focused on their roles (e.g. Huzzard et al., 2010) and coping mechanisms (e.g. Sillince and Mueller, 2007) at the expense of understanding their lived experiences of work. The limited exceptions have arrived at inconsistent results. On the one hand, existing research characterizes boundary work as triggering openness, fluidity and a sense of autonomy in dealing with multiple competing demands and situational requirements (Sveningsson and 
Alvesson, 2003). On the other hand, such work may give rise to feelings of separation, tension and a sense of otherness (Beech, 2011). The fact that middle managers can harbor such heterogeneous experiences begs explanation. Thus, the current study focuses on the question of how the role complexity and tensions ensuing from boundary work are experienced by middle managers.

To answer this question, the next two sections discuss the contradictory pressures exerted upon middle managers when performing boundary work, and the ambivalent position these pressures establish for managers. We then describe our ethnographic engagement with a Brazilian accounting firm, where we followed middle managers during the course of their daily organizational lives (Courpasson, 2017) to produce thick description (Geertz, 1973) of their subjective experiences of work. Our findings examine the diversity of reactions to boundary work, including not only a sense of liberation and autonomy, but also of suffering and social detachment. Empirically, in order to explain this ambivalence, we build upon and elaborate concepts of emancipation and alienation, allowing us to theorize their co-emergence within complex managerial roles by proposing a taxonomy of experiential categories that encompasses the range of experiences encountered during the routine course of middle managers' work. Based on this resulting theorization, we draw out a research agenda for examining emancipation and alienation in professional work, and consider its implications for our understanding of managerial work.

\section{LITERATURE REVIEW}

\subsection{Ambivalence in Middle Managerial Work}

There is no unanimously accepted definition of middle managerial work (Harding et al., 2014). For our purposes, we characterize middle managerial work as work carried out by organizational members who interact regularly with both top executives and operational employees (Wooldridge et al., 2008), involving the performance of multidirectional roles 
(Bryant and Stensaker, 2011) and serving as a conduit between ranks (Nielsen, 2009), so as to interpret and translate abstract strategic vision into practical implementation (e.g. Huy, 2001).

Given their organizational responsibilities and positioning, middle managers cope with "conflicting expectations and frustrating demands" (Keys and Bell, 1982: 59), routinely facing contradictory work situations (Sims, 2003). Moreover, middle managers struggle to deal with both upward and downward relations within the organizational hierarchy, as well as with groups both internal and external to the organization (Rouleau, 2005). This multidirectionality presents difficulties given the conflicting attitudes, skills, requirements and exigencies demanded of a single individual by different groups (Keys and Bell, 1982).

Research on middle managers' lived experiences while dealing with these contradictory influences has identified a multitude of responses. Clarke et al. (2009) demonstrate three contradictions stemming from middle managers' disparate sources of influence: their accounts suffer from a lack of coherence in incorporating conflicting elements, their identities display conflicting features, and they are shaped by organizational controls at the same time as they resist these controls. Harding et al. (2014) further show that middle managers' status involves perpetual shifts between being agents of control and being subjected to control - they are resisted and themselves resist, resulting in a plethora of routine positions that renders their work difficult to comprehend.

Organizational roles provide mediating structures that allow subjects to navigate this complexity (Järventie-Thesleff and Tienari, 2016). Scholarship around roles has considered the subjective importance of transitioning across roles, particularly in terms of identityrelated processes (e.g. Ashforth et al., 2000; Simpson and Carroll, 2008). However, the subjective experience of work cannot be reduced to role occupation, and while the ongoing shifts between control and subjection experienced in such intermediate positions has been 
noted (Harding et al, 2014), little is known about the subjective experiences of agency or powerlessness as middle managers enact different persona across organizational situations.

Such ambivalent experiences derive both from middle managers' work situation and their social position (Thomas and Linstead, 2002). According to Peschanski (1985), both in their work and social lives, middle managers occupy intermediary positions between the capitalists and the workers, between the bourgeois and the proletarian, rendering their standing more contradictory than in the case of any other social stratum. Situated between spheres of influence, middle managers are exposed to, and are required to cope with, contradictions and tensions of empowerment and exploitation. As such, middle managers' situation can be described as a pull between their "state as subjects" (Courpasson, 2017: 855) - in which the relationship of middle managerial individuals to their surroundings involves experimentation, recognition and reflection - and as mere "reacting objects" numbed by dominating situations (Blauner, 1964: 16).

Although some work has examined the ways in which middle managers tackle organizational contradictions (e.g. Beck and Plowman, 2009), and the impact these contradictions have on middle managers' identity (e.g. Sims, 2003), emotions (Turnbull, 2001), language usage (Watson, 1995) and career progression (Kornberger et al., 2011), the subjective experiences of being both agent of action and object of control suggests an ambivalence that is not well understood. Out of the frictions between these contradictory possibilities of human existence, the ontological possibilities imagined by individuals may be rendered unpredictable, and everyday politics indeterminate.

\subsection{Middle Managerial Boundary Work}

The ambivalent position described above results from middle managers' work in coordinating different actors across hierarchical and functional lines (e.g. Balogun et al., 2005). Promoting and coordinating action is a classically recognized managerial task 
(Mintzberg, 1990), involving struggles between divergent agencies and interests (Clegg, 1989). Although such coordination has important repercussions on organizational functioning, it has been a persistent academic puzzle (e.g. Delmestri and Walgenbach, 2005; Fayol, 1916/1979; Mintzberg, 1973). While some studies have identified "universal" managerial roles - arguing, for instance, that managers are required to perform decisional, informational and interpersonal roles (Mintzberg, 1973) - other research has demonstrated the existence of divergences as well as similarities across contexts. For instance, the German, Italian and British middle managers studied by Delmestri and Walgenbach (2005) mobilized technical and managerial knowledge to varying degrees; yet, their managerial work was similar in that they shared the responsibility of buffering between groups in order to maintain a positive social environment, attain goals and retain organizational flexibility.

Thus, with middle managers, facilitating collaborative action also implies navigating between different organizational publics. Given their need to understand both the technical and social aspects of organizations (Huy, 2001), middle managers capitalize on both informal and formal channels of communication and foster cross-functional collaborations by influencing key organizational actors (Rouleau and Balogun, 2011), negotiating between the strategic and operational levels of an organization. We call the activity of working between these actors "boundary work".

Existing literature has mentioned boundary work as a way of establishing and maintaining group divisions (Lamont and Molnár, 2002); however, the structural focus of this work neglected the micro-interactional aspects of boundary work (Okhuysen et al., 2013). To focus on this micro-level and its experiential possibilities, we use the term boundary work to evoke the ways in which middle managers' work mimics the role of boundary objects, by catalyzing intergroup collaboration via interpretive flexibility across, or local tailoring to, diverse groups (Star \& Griesemer, 1989). Drawing the parallel between middle managers' 
work and boundary objects highlights the definitional ambiguity of middle managers' status within organizations.

Boundary objects are characterized by their lack of a specific definition and by their continuity across a range of possible categorizations (Star and Griesemer, 1989). To produce coherence among divergent contributing social worlds, boundary objects simultaneously assume seemingly contradictory positions (Star and Griesemer, 1989), serving as spaces of negotiation in which differences and information are articulated, amended and transferred. Boundary objects allow actors to cope with and overcome problems arising at the interfaces of different spheres of activity, and are perceived differently by different actors.

Unlike boundary objects, however, middle managers do not only "sit in the middle of a group of actors with divergent viewpoints" (Star, 1989: 46), they also actively constitute and enact their position and work (Harding et al., 2014). Thus, individuals - such as middle managers - are not (merely) objects, in that they are not passive "linking pins" (Harding et al., 2014). Rather, they also consciously and reflexively regulate their boundary-negotiating activities and standings, and, in this way, subjectively experience their positions as ones of possibility or constraint. For this reason, we refer to middle managers as "boundary subjects" (Huzzard et al., 2010).

Huzzard et al. (2010) used the concept of "boundary subjects" to describe action researchers as they practiced research interventions at the boundaries of coalitions with the aim of cultivating inter-organizational cooperation. While mediating between different groups, boundary subjects encouraged mutual reflection and constructed shared meanings, emphasizing diversity while also securing agreement on ways of working, and building relationships and coalitions through dialogue. Through these activities, boundary subjects influenced the parties involved, thereby facilitating collaboration. 
Similarly to boundary objects, boundary subjects mediate between heterogeneous groups to achieve collaboration. However, while boundary objects serve diverse constituencies through their receptivity to multiple interpretations (Star and Griesemer, 1989), boundary subjects enact these socially constituted worlds (Huzzard et al., 2010). Performing their roles in political and discursive ways and, as subjects, subjectively experiencing their mediational role, boundary subjects make sense of their intermediary positions as the enactment of boundary work.

The notion of the boundary subject is useful for characterizing the experience of work at boundary interfaces, an increasingly important area of study (Laine et al., 2016). Yet the concept appears only in two recent studies (i.e. Huzzard et al., 2010; Laine et al., 2016), and has not been applied to middle managers, a group uniquely poised as boundary subjects. Nor has the experience of such a subjectivity, and its inherent ambivalences, been empirically explored. Despite this lacuna, the concept provides us with an analytical lens through which to examine the work of middle managers in their agential and subjective experience of intersectional work at the crossroads of organizational groups.

\section{METHOD}

Middle managers have been studied using both quantitative (e.g. Pappas and Wooldbridge, 2007) and qualitative (e.g. Mantere, 2008) methods. However, a recent review of over sixty years of literature (Korica et al., 2017) finds few examples of deep ethnographic engagement in middle managers' daily lives. Prioritizing the lived experience of middle managers in their ambivalent experiences of agency and instrumentalization in everyday experience, our study began from a broad ethnographic strategy. This involved immersion in our subjects' daily lives and activities and closely observing and recording behaviors, relations, structures, symbols and meanings, with the aim of writing detailed accounts of these subjects and their culture. 
Despite the lack of a rich ethnographic tradition on middle managers, related work exists on professional services firms (Watson, 2011), work-embodied practices (cf. Barley and Kunda, 2001), emancipation in organizations (Alvesson and Willmott, 1992) and the control/resistance dichotomy (Prasad and Prasad, 2000). Following this work methodologically, we foreground our focus individuals' capacities to actively create the world and themselves via everyday mundane actions, encounters and life experiences shared at work (Courpasson, 2017).

\subsection{Background of the Studied Firm}

BRABIG ${ }^{1}$ was founded in 1965 and is among the twelve largest audit firms operating in Brazil. BRABIG's main services are auditing of financial statements and internal controls, information security auditing, and consulting. Table 1 presents BRABIG's personnel structure, as described by the firm's directors and HR department, indicating the number of people in each office location per organizational rank. The personnel structure has four ranks: top management, middle management, auditors and consultants (also called staff), and backoffice. Middle managers are located between top managers and staff.

$$
\text { <insert Table } 1 \text { here> }
$$

\subsection{Data Collection}

The ethnographic fieldwork, conducted by the first author in an open and emergent manner with research questions emerging from the field (Van Maanen, 1998), lasted until theoretical saturation was achieved. The larger context of the study was the daily work lives of middle managers, with an emphasis on interactions with top managers and subordinates in formal (e.g. meetings and training sessions) and less formal (e.g. everyday work and lunchtime) conversations and situations.

\footnotetext{
${ }^{1}$ A pseudonym.
} 
Fieldwork, consisting of observations, shadowing and interviews, took place in two phases - August-October 2011 and February-June 2012 - across four offices, selected for their size and strategic importance: the firm's headquarters in Porto Alegre and branches in São Paulo (two offices) and Rio de Janeiro. Initial insights about the performances of boundary work derived from observations and shadowing; however, we relied largely on interviews to understand and convey informants' experiences of such a work. We interviewed middle managers, their direct supervisors, subordinates, and colleagues regarding their work practices and interpersonal relations. A multi-angle approach was adopted, with responses of different interviewees cross-verified and interviews repeated to aid in identifying recurrent themes. A first phase (in 2011) of individual open-ended interviews (around thirty minutes each) with 40 BRABIG personnel in general, focusing on work responsibilities, practices and relations, was followed by a more focused, in-depth, second phase (in 2012) of individual recurrent interviews (4-9 hours with each manager) with 12 middle managers. The interview script of the second phase was informed by our reading of the pertinent literature as well as our analysis of the data gathered during the first phase. These structured interviews were designed with the specific aim of gathering, among other information, insights into matters relating to the quality of "in-betweenness", the challenges and pleasures arising from mediating between heterogeneous groups, and the interviewees' successes and failures in establishing cross-functional collaborations.

All interviews were recorded, with the exception of those of two participants who, in the first phase of interviews, felt uncomfortable being recorded despite being guaranteed anonymity - for these two cases, notes were taken. All observations and interviews were conducted in Brazilian Portuguese. All interviews were transcribed verbatim into Portuguese by the first author. Only the interview extracts used in the paper were translated into English by the first author and verified by the second author, fluent in both English and Portuguese. 
Minor disagreements in translation to English were solved by giving preference to the author whose first language is English. A summary of interviewees' details is given in Table 2.

< Insert Table 2 here >

\subsection{Analysis}

The first insights around boundary work occurred during observation and shadowing, when we noticed that middle managers' ways of working and presenting themselves were continuously tailored to their environments and roles. Middle managers' intermediary position became evident during the observation of key managerial activities (e.g. interfacing, conveying information and knowledge, and translating between organizational groups and ranks) and in response to situational requirements (e.g. the need to appease, and the need to render information comprehensible and coherent).

Our data collection and analysis co-evolved iteratively (cf. Corbin and Straus, 2008), with initial observations of everyday work practices followed by interviews more directly interrogating middle managers' subjective experiences. Our initial focus on work moved inductively into a consideration of interpersonal relationships organized around interfacing roles, where the in-between condition of middle managers' work became a central concern. Thus, our focus of analysis shifted to middle managers' interactions and social role positioning. At this point, gaining access to the experience of being subjected to this kind of positioning required direct interviewing techniques. As such, as noted above, our final experiential categories drew heavily on the interview data. Taking intermediation as a conceptual object led us to envision this aspect of middle managerial work in terms of the functions performed by boundary objects. From the concern with lived experience and the emerging considerations about boundary work, we decided to build upon Huzzard et al.'s (2010) notion of boundary subjects as our "sensitizing concept" (Blumer, 1954). 
Specifically, we focused on middle managers' responses to boundary work: how they thought about it, felt about it, and perceived its deployment. Two overarching themes emerged, encompassing the experiential categories of emancipation and alienation as undertheorized features of middle managerial work. We organized similar pieces of empirical evidence into salient categories, some associated with a sense of liberation, proficiency and freedom, and others linked to frustration, disorientation and detachment. We began to view these two aspects as dialectical, deriving from and acting through opposing forces, hence conceptualizing middle managers simultaneously as being boundary subjects and as serving as boundary objects for the purposes of the organization's functioning.

Beyond cataloguing different experiences of boundary work, we sought to theorize emancipatory and alienating experiences as related parts of a more general phenomenon. Emancipatory and alienating experiences of boundary work were conceptualized in terms of their mutual reinforcement within a unified field of experience. Furthermore, the two themes appear in different ways across the categories demonstrated in the Findings section. ${ }^{2}$ The overarching themes do not describe a single positive or negative experience, but rather a thematic range involving ambivalence, uncertainty and contradictory experiences.

The authors met frequently to discuss the empirical material collected and the dynamics witnessed by the first author in the field, helping to shape the emerging categories and allowing for systematic evaluation of judgments regarding the evidence. Although our ongoing engagement with the literature informed the analysis, our concern was to allow the research findings to emerge from the empirical material itself, linking it with, but not being constrained by, pre-existing theoretical frameworks.

\footnotetext{
${ }^{2}$ As for instance elaborated in the 'reflexivity' category below.
} 
Table 3 demonstrates our conceptualization process and some empirical material employed: i) illustrative codes generated from field notes (observations and shadowing) about boundary work, which assisted us in developing interview scripts to capture how managers experience this work, ii) illustrative extracts from interviews we draw upon to develop the theoretical categories, and iii) the aggregate theoretical dimensions that encompass the emancipatory and alienating experiences of boundary work.

< Insert Table 3 here >

\section{FINDINGS}

\subsection{Experiencing Emancipation}

The experience of being a boundary subject involved what we call "emancipation" when boundary work allowed middle managers to improve their craft, offered autonomy across diverse functions and ranks, established possibilities to access influential actors, and triggered critical thinking. The four experiential categories we identified under the overarching supercategory of emancipation - mastery, autonomy, empowerment and reflexivity - are analytically distinct, despite being phenomenologically related in their common emergence from boundary work.

\subsubsection{Mastery}

Mastery of boundary work was experienced as proficiency in adapting to multiple roles, several times a day. Interfacing across, and crossing over, functional and hierarchical boundaries was deemed important for task completion and cross-collaboration. As $\operatorname{Marcos}^{3}$, a young manager responsible for government projects, said regarding a Lottery audit project:

This matter about the [auditing of the] lottery and its contracts, I am not gonna fix it [by myself], I am gonna make people talk. Then I'll go and make these four [departments] sit down and resolve the matter. That's what I'll do; it's a mediation of conversation involving four different areas.

\footnotetext{
${ }^{3}$ All interviewee are middle managers and have been given fictitious names to protect anonymity.
} 
Alexandre, who has worked in several different areas and branches of BRAGIG, reported that the skills required to perform boundary work are rare and valued: "Even the directors don't have the knowledge to resolve these problems because the one who is transitioning among all these levels is me”. Tiago, responsible for BRABIG's most important business unit, took pride in the creativity inherent to this adaptability, reinforcing the sense of mastery: "To play these different people [roles] is the art of an intermediary manager."

Selling seemed to be acutely dependent on mastering boundary work, its inbetweenness and requirement for juggling a diversity of knowledge bases and relationships. Leonardo, a branch manager known for his intelligence and political skills, noted, regarding working at organizational crossroads: "A service is not sold without having technical knowledge of the matter. So, this line places me in a position to act on any of the corners of the [organizational] tripod, that is, the technical, administrative and commercial".

Leonardo's comment suggests the multifunctionality and varied knowledge bases required to successfully expand businesses, and how these are concentrated in the middle manager's role.

During observations, it was noted that middle managers discussed the importance of flexibility and adaptation as performance elements within their teams. They cited this capacity as key to career progression. As documented in the field notes:

In a training session, Tiago instructs his senior auditors that to be a real project leader they should be flexible and adapt their behaviors according to the clients' interlocutor: stricter and more direct with the accountants and friendlier and more talkative with the finance director.

Felipe, a branch manager known as BRABIG's best salesperson, mentioned that roles like "leader" and "follower" would frequently alternate during work - "I am a follower, and also I am a leader" - indicating several possible configurations of professional domain and hierarchical position. A similar point was made by Jorge, an experienced special projects manager, who added a reason for such role accumulation: "Firstly, I am an engineer. I am no accountant... I helped establish the consultancy... I am a supervisor, a manager, a director 
because when I am working with a team with a client, or in a meeting, I have to defend the project and the firm."

On a regular working day, middle managers were observed transitioning across, and acclimatizing to, diverse organizational groups and situations, and engaging and disengaging with distinct roles (e.g. director, organizational psychologist, auditor/consultant, auditing partner, business unit manager, sales person and team leader), as corroborated by Tiago: "Changing roles is a necessary part of the managerial work; that is, it is a function of the one who is between the ones who have the capital and the ones who have the labour [to offer]." Tiago here explicitly acknowledges the position between capital and labour as the root of the ambivalence of boundary work. This ambivalence extended to interpersonal relations, as Marcos notes, suggesting that mastery of boundary work connecting distinct agendas is an important professional asset: "To be a good manager here you cannot communicate as you wish and only in your own way, you have to adapt, to be able to transit in the different hierarchical levels and among people with different sorts of personalities."

Thus, by mastering boundary work, middle managers as boundary subjects experienced a sense of proficiency in accommodating contradictions, a situation reported by João, the manager of a new service line: "If I don't defend, simultaneously, the interests of the team, the directors, and the client, the client would leave, the employees would quit and the directors would lose all their profit." His remarks indicate the in-betweenness of boundary work, its political intensity and inherent juggling of contradictions, suggesting that harmonizing interests facilitates keeping the organizational ensemble operating properly.

\subsubsection{Autonomy}

Autonomy involves the experience of enjoying latitude and discretion, resulting from opportunities for open and creative juggling of roles and organizational groups. Informants 
described their mediational work as "free," and reported having space to draw upon diverse functional areas and construct a broad network of relationships.

Performing, changing and adapting boundary work on an ongoing basis led middle managers to experience autonomy in making their own choices - "I have a capacity to do and to be in all the areas, and to tailor myself to them" (Alexandre) - and to prize such a liberty: "For me it is a much greater personal satisfaction playing these various roles than only one. It is not only a pleasure; it is also a professional achievement" (Tiago).

Boundary work was associated with autonomy, conveying a sense of freedom from a single categorical organizational role through intermeshing, and working within, multiple domains: "I do not belong to a single job, I belong to 200 jobs. So I have to be open to all of them at any moment" (Felipe). Carlos, known for his dynamism and capacity to keep abreast of new norms and regulations affecting audits, believes he has ample leeway to choose his roles: "It's you that chooses the roles you will develop. This gives you a certain freedom."

However, as indicated in the field notes, shadowing middle managers revealed that this sense of autonomy also generated animosities, mainly when middle managers: i) encroached upon the autonomy of other managers by dealing with other branches' matters or clients outside of their jurisdictions, ii) attempted to get involved in BRABIG's cash flow matters for which the headquarters finance department was exclusively responsible, or iii) tried to influence the auditor's opinion document - the final product of auditing engagements and a legal prerogative of audit directors.

\subsubsection{Empowerment}

As boundary subjects, middle managers experienced a feeling of empowerment when the opportunities created through boundary work led to a sense of responsibility and authority, sometimes exceeding that of their officially sanctioned position in the organizational hierarchy. Tiago, for instance, believed his responsibilities extended to taking 
care of all aspects of organizational functioning - "You represent the role of a steward of a farm" - while Daniel, a manager with a great reputation among clients and regulatory bodies, felt empowered by the authority granted to him by top managers to mitigate problems: "When top management tells me: 'that is your problem,' it relocates me higher in the hierarchy, to a position at the top. I have to solve it [the problem]... and then top management has no interference... the decisions are mine."

Top managers were observed treating middle managers as equals and encouraging them to operate on their own. Middle managers, such as Felipe, often enacted the directors' role, and were recognized as top managers by coworkers ("Here in the branch there are people who call me director") as well as by themselves ("My role mixes up with that of a director"). As documented in the field notes:

Middle managers often introduce themselves as directors, and top managers often present middle managers as peers (e.g. to potential and actual clients and subcontractors).

Relations with clients were reported as situations empowering middle managers: "The technical part [of the work] is more middle, the administrative part is middle to the top, and in the commercial part we are practically directors" (Alexandre). These external relations were crucial to organizational performance and were usually led by middle managers: "Most of the time the clients think I am the director in their projects. And then, I act as a director at that moment... because if I do not play the director with the client, most often I do not have [keep] the client" (Leonardo). In short, boundary work was linked to the experience of empowerment via the possibility to perform prestigious, "upgraded" roles, with heightened levels of responsibility beyond the middle managers' official roles.

\subsubsection{Reflexivity}

A key aspect of middle managers' experience was their heightened sense of reflexivity. Reflexivity involved the experience of being aware of oneself as an observer, 
resulting in the capacity to contemplate one's own actions as if at a distance. Boundary work gave rise to the experience of reflexivity because of its constant requirement to reconfigure action patterns and step outside of given scripts. Pedro, the manager responsible for international clients, describes how such work requires the creation of a space outside of action: 'It's hard to imagine, but sometimes I think that there's an empty space between the different roles. But no-one sees it, it's challenging, you have to have talent to manage it, it's not recognized but at the same time it's a nice sensation". Middle managers' reflexivity was linked to the decoupling of the self from any single role. As Tiago expressed: "There's the feeling of you not being yourself. Many times you have to perform many roles but none of them is really me. But was I hired to be me, or to be a manager?" In this quote, Tiago questions the insecurity and the sense of a lack of authenticity triggered by a work experience marked by constant adaptation to distinct roles. He suggests that being a manager requires performing roles that are not the self he would like to express at the workplace.

Thus, despite harboring doubts about whether their actions correctly addressed organizational and personal expectations, middle managers enacted multiple repertoires as part of their normal work experience. Informants reported that they did not know the exact contours of their responsibilities and prerogatives, questioning whether this fuzziness impacted organizational functioning and performance: "I would be more effective if I knew the range I can go to without being questioned by the directors, the range of my responsibilities. I don't have a job description" (João).

During observations, it was noted that middle managers tended to reflect at length on their own jobs, spontaneously bringing up self-examinations about what they were doing, what group they belonged to, and where they "found themselves" in their work. For instance, as noted in the field notes:

Leaving a meeting with a subcontractor [a law firm], where the two representatives of this subcontractor were directors and in which a deal was made, Alexandre vented to 
me his preoccupation about whether he had the legal authority to make such a deal, even though BRABIG directors had sent him alone to represent the firm.

Middle managers' role as de facto directors was also considered ambiguous: "I am in practice and not in principle. I am often treated as a director, but I am not" (Alexandre). Despite often enacting the director role, middle managers knew they were not directors. While providing prestige and recognition, this aspect of boundary work was considered suspicious, given top managers' possible instrumental deployment of it: “I am treated by top management as a director - de facto but not in principle... I am often introduced as a director. They [top managers] use that a lot" (Jorge). Taking on a director's role, and the more general lack of a stable set of meaningful roles and their impermanence over time, generated both a sense of empowerment and reflexivity, leading middle managers to question their place in the organizational hierarchy and their possibilities for discretion and action.

\subsection{Experiencing Alienation}

In contrast to the experiences described above, as boundary subjects, middle managers also experienced alienation through the ongoing demands for achieving collaboration between divergent interests and for occupying shifting roles. Middle managers sometimes expressed the feeling that such demands were externally driven rather than freely chosen, and diverted them from deepening their professional knowledge and their intimacy with colleagues. These experiences, in which middle managers framed boundary work as something endured rather than something achieved, are demonstrated and discussed below under the following four categories: fatigue, lack of self-determination, detachment from profession and detachment from coworkers. As with the experiential subcategories under the category of emancipation, these sub-divisions are analytically distinct but phenomenologically intertwined in everyday experiences of middle manager boundary work.

\subsubsection{Fatigue}


Boundary work produced fatigue, resulting from the subtle yet ongoing effort of finetuning roles while remaining sensitive to diverse audiences. During fieldwork, the researcher noted Leonardo's fatigue on the days a headquarters director visited his branch office. As documented in the field notes:

In the early evening, when just a handful of people remained in the office and most lights were off, Leonardo vented the fact that he was exhausted because of the effort to constantly switch between subordinate and boss roles during that day.

Middle managers reported the burden in regularly improvising their day-to-day activities: "I find it strange and tiring when you have to change hats so many times each day, every day" (Alexandre). Changing and adapting roles to interface between different groups was seen as shifting between "realities", a challenge to be surmounted, requiring continuous attention, learning and effort:

Up to the moment I understood the various political forms of how to strategically address myself, it was a challenge, it was a difficulty.[...] Then you understand that politically you have to have such a posture toward this [group], and that before such [group] and that before such [group]. (Leonardo)

Fatigue was more acutely experienced in the following four cases. First, boundary work involved a greater degree of effort when distinct audiences were present at the same time in the same environment, as described by Felipe:

There is an effort to change roles when directors are here. And then I interact with my team having the director around me. I think there is an effort due to having to make things [messages] more palatable. One thing is to discuss with the director over the phone and then transmit the matter to my team without having the director around. Another thing is to, having the director beside me, transmit to my team something that I know he told me in a different way... So, then, yes there is a difficulty when directors are here... And to transmit a message having the original sender of the message by your side generates a larger than usual effort.

Second, unexpected performances were also especially delicate, as Tiago exemplifies:

I found myself playing as if I was the commercial manager of [the PR branch office in] Curitiba, and I am not even the commercial manager of São Paulo [the branch he works for]... it was a role that I was not prepared [to perform], it was an impromptu performance. 
Third, branch middle managers experienced more boundary work, and thus greater hardships, than their counterparts from headquarters: "the geographical remoteness of the directors increases the number of roles and the frequency of shifting between them" (Daniel).

Finally, boundary work seemed to present a greater difficulty for early-career middle managers: it is a laborious process demanding several years of practice and learning. When asked about the multiplicity of roles, Tiago declared:

It is natural. It is natural because I have been doing that for 15 or 20 years [long pause] so it is natural, it is natural today, huh! It was not natural 15 or 20 years ago. I consider myself a coordinator or a manager since 1997... So today it is natural that I play these various roles because of my experience. In 1997 it was not natural... But now I see this is a matter of survival in these types of positions.

In short, the movement involved in boundary work, just as it opened up spaces for activity and possibility, increased the demand for energetic and active role-improvisation, leading to additional work demands and fatigue.

\subsubsection{Lack of Self-Determination}

Lack of self-determination describes the demand for adherence to others' expectations and conventions, and the feeling that action is not truly determined by one's own will. Tiago describes such an experience metaphorically, explaining that, despite the putative empowerment of his position ("It's a fact that you are director and actor at the same time"), his freedom is actually an illusion and his actions are externally driven: "You have to play several characters [roles], and it is you who decides which to perform. But the liberty you have is a function of necessity. You have liberty but are not always driven by yourself." Thus, factors external to middle managers' control impose a certain role and script to be followed, suggesting that the freedom middle managers have when transitioning between and performing different roles is only apparent. 
Informants, such as the manager responsible for the audit engagement logistics,

Carolina, reported not feeling in control of their conduct and actions, of being obliged to adjust to others: "Because you are in the middle you have to mold yourself on both sides."

Middle managers often complained that, though they were given many

responsibilities, they were faced with reduced possibilities for action and ambiguous directives that could be contradicted at any time. They used the term "desmando" (counterorder) to describe such situations. As indicated in the field notes:

Felipe arrives in the office looking very irritated, randomly walking around the office space. He then comes closer to the staff area, interrupts Carlos who was debriefing a junior auditor, and starts talking. He says he had just lost three weeks of work and lots of money in commissions because of a headquarters director, who in a last-minute decision, augmented BRABIG's price in a public bid, bypassing Felipe's orders. The result was that BRABIG did not get the contract. He goes on saying that the winning firm, a competitor with cost structure similar to that of BRABIG's, offered a price slightly higher than the price that Felipe had estimated for the service - thus attesting to the fact that his estimation was appropriate, but making him even more angry and frustrated.

Maria, who was somehow involved in virtually every technical aspect of BRABIG's audit engagements, is emblematic of the prevailing attitude of boundary subjects. Maria believed that her work dictated some behavioral norms and perceived requirements, and that, as such, she behaved in predetermined ways: "You have to be dynamic, political, open; you cannot be strict." Middle managers were continuously being watched by, and needed to both respond to and influence, others. Thus, middle managers resorted to boundary work via the exertion of conscious and continuous diligence to choose the right role performance for a given situated interaction, yet they lacked self-determination regarding their performances.

Furthermore, by being systematically context-sensitive, middle managers also had to reconcile multiple concerns: "Diplomatic people are interested in relationships, and technical people are interested in numbers; but I have to be both" (João). Continuing his argument, this informant suggests that lack of self-determination ends up compromising one's professional pursuits - "Usually a person specializes in an area, but I see myself [as 
being] forced to learn from all departments" - to the extent of leading one astray from his/her profession, an alienating experience discussed below.

\subsubsection{Detachment from Profession}

Detachment from profession denotes the experience of being distant from the craft or professional expertise of one's work. Boundary work and expert work represented competing demands, vying for middle managers' busy agendas. BRABIG middle managers experienced their work as being that of constantly having to "fix things" between actors:

The Auditing [department] understands things in a way, the Planning [department] understands things in another way and the Finance [department] understands things in another different way, about the same contract. So you have to have a harmony... then you have to link them. (Alexandre)

Auditors, whether junior or senior, were often noted to describe themselves as "auditors", while middle managers, also auditors by profession, would describe themselves as a "business person", a "manager" or a "sales person." The fieldworker observed that middle managers, in contrast to auditors, spent little time reading accounting regulations or legislation, or attending professional society training sessions. As noted in the field:

When middle managers have to attend more technical meetings, that is where auditing, accounting or taxation matters were in the meetings' agenda, they are accompanied by a senior auditor to be sure that the technical issue would be handled properly.

Moreover, leading people and projects was also time-consuming: "I'm not a sound expert... I'm not a technician, I define the coordination" (Felipe). Middle managers were trapped in a situation perceived as being devalued and precarious: "This work of sitting in the middle doesn't feel constructive... it has a rhythm and you go with it, and it seems never to add up... I would like to build up something" (Maria). Thus, rather than developing sound auditing and/or accounting expertise, middle managers felt doomed to mobilize several knowledge bases as a daily and recurrent dimension of their working lives: "I will not get good at anything, I am superficial in everything... The need to guide them [staff] makes me read a little of everything" (Carlos). 
In contrast to what would be expected from an auditing expert, middle managers were routinely involved in negotiating demands and facilitating dialogues across groups - "I think that this [work] is basically pure good communication, which you have to have, and someone has to play the carrier pigeon" (João) - and in steering relations between parties with divergent interests. The analogy with the carrier pigeon suggests the idea of conveying a message that is not one's own, and is distant from the image of an authoritative professional. Boundary work distanced middle managers from their profession, leaving them with the feeling of not undergoing professional development or deepening their professional expertise.

\subsubsection{Detachment from Coworkers}

Boundary work drove middle managers away from, and obstructed the possibilities of getting acquainted with, their colleagues. At no time during observations did branch middle managers have lunch with their coworkers, even when these managers spent the entire day in the office. ${ }^{4}$ The field notes point out that:

Middle managers tend to not take part in the everyday chats around smoking areas or the "little coffee" breaks (cafezinho), important moments in BRABIG's Brazilian work culture.

Despite dealing with a multitude of people and groups every day, boundary subjects felt exploited by their coworkers, experienced loneliness, and suffered from relations of rivalry with their peers, as elaborated below.

Boundary subjects invoked a feeling of being objectified by work colleagues, who used them instrumentally:

I think you become a functional object. You are a mere mainspring of a gear that needs you to function; things need to "go through you." [...] it is good for the firm, the firm needs that person. For me? I do not know if it is good. It has side-effects. Ah, I am a facilitator, I bring information from management and the Board and I will make the wheel turn down here [staff]. I think there is a certain artificiality about it. I think

\footnotetext{
${ }^{4}$ A similar observation was not possible at headquarters given its size, facility design, and personnel magnitude.
} 
people start to see you as being this, this cog in the gear that makes the gear function, and people stop seeing you as a person. (Tiago)

Corroborating this sentiment of being used and having to serve others, Leonardo noted extreme instances of discretionary de-personification: "I do not have to have an ego, I cannot have an ego. I think that more than ever the leadership has to be based upon this detachment regarding vanities." Such a statement shows his work as downplaying his sense of identity.

While adapting to the instability of roles and demands was necessary, it also led our managers to conceal their thoughts and feelings, finding themselves to be isolated and disconnected from personal relationships:

One negative thing deriving from playing these several roles is a certain loneliness, despite having relationships that could be expanded in terms of friendship with people who live with you so many hours of the day. (Carlos)

Middle managers commented that they did not consider coworkers as people with whom they could discuss intimate matters regarding working conditions and situations: "The feeling of non-inclusion is total... being a manager is not being included in anyone's group." (Daniel). The transitional, shifting work of boundary subjects left many respondents distrustful of other middle managers, whom they reported as duplicitous and difficult to read.

These perceptions contributed to the sense of rivalry experienced by middle managers. It was observed that middle managers did not feel comfortable in the presence of, and did not trust, their peers, as Leonardo attests:

Top management has a very frank way of treating you, as a rule. People from the base [subordinates] give you very frank treatment. When you are relating to your peers, you have a different situation. I have no difficulty handling it [lack of frankness from other middle managers], but I think I will always have difficulties understanding this animosity.

As a result, boundary work prompted middle managers to experience alienation from coworkers, rendering them unable to nurture trust bonds and comradeship in the workplace.

\section{DISCUSSION}


Our findings shed light on the ambivalent lived experience of middle managers as boundary subjects, vacillating between feelings of emancipation and alienation. Carrying out boundary work gave rise to diverse reactions, which we divided into two experiential categories - 'emancipation,' involving the senses of mastery, autonomy, empowerment, and reflexivity promoted by boundary work, and 'alienation,' involving fatigue, lack of selfdetermination, distancing from one's profession caused by performing roles unrelated to it, and difficulties in nurturing authentic personal connections in the workplace.

Our contribution to the understanding of middle managers' work lies in this exploration of the ambivalent feelings of emancipation and alienation deriving from their position as boundary subjects. Rather than describing emancipatory acts though resistance activity (cf. Courpasson and Vallas, 2016), we problematize the distinction between emancipatory and alienating experiences by exploring the heterogeneity of experiences pertaining to a given activity. To do this, we have explored how middle managers' work both enables them to access multiple organizational action spheres in order to leverage their professional and personal pursuits (e.g. Kornberger et al., 2011), while, at the same time, generating subjective feelings of alienation from their profession and coworkers.

These ambivalent reactions are summarized in what Courpasson (2017) called forces of emancipation and alienation. While emancipation and alienation are often considered as opposing work regimes or practices (e.g. Alvesson and Willmott, 2002), focusing on subjective experience opens up the possibility that both may co-exist within a similar horizon of lived experience. The ambivalent intermingling of emancipatory and alienating experiences in the daily lives of our middle managers suggests a more complex interpretation of managers' work experience.

Similar to recent treatments of "high-involvement" work (Ekman, 2014), the experience of ambiguity can create opportunity, but also uncertainty and a loss of bearings. 
Such research has shown that contemporary work settings juxtapose exploitative and expressive elements in ways that make monological readings of the workplace untenable (Endrissat et al., 2015), complicating attempts at critique. Rather than considering emancipation and alienation experiences as simple opposites, our findings frame the two as cohabiting in middle managers' ambivalent responses to the exigencies of boundary work. The openness, multi-role demands, and in-between nature of boundary work were experienced in contradictory ways that were held together in experience. Indeed, middle managers' boundary work made them experts at holding together lived experiences of difference, an emancipatory capability that also brought with it a kind of suffering. How this duality informs current discussions of emancipation and alienation is discussed below.

\subsection{Contributions to Emancipation/Alienation Literature}

Alienation is traditionally considered in relation to the commodification of labour power and workers' loss of control over, and consequent distancing from, the means of production and social relations (Marx, 1844/1988). The structural condition of alienation renders workers a passive object of history, distanced from the possibility to fully develop their human potential (cf. Schacht, 1970). This has led critical labour scholarship to focus on issues of workers' loss of autonomy - for instance, through de-skilling in industrial settings (Braverman, 1974). Later literature problematized the relation between de-skilling and the loss of autonomy (e.g. Hodson, 1996), with the suggestion that alienation and emancipation may trade off in different ways across work contexts. Moreover, more recent work locates notions of alienation in non-industrial settings with demands for feigned authenticity and identification (e.g. Costas and Fleming, 2009).

Conversely, emancipation has been discussed in terms of the material, intellectual and psychological freedom from conditions of domination (e.g. Laclau, 1996). Applied to organizational settings, emancipation has been used to highlight situations of autonomy. 
Focusing on the case of workplace politics, Courpasson (2017) characterizes emancipation as the creativity, freedom and inventiveness that individuals manifest at work, and alienation as the constraining and oppressive aspects of work and routine productive activities, and the consequent sense of frustration and suffering on the part of the individual.

Across these various conceptualizations, emancipation and alienation oppose each other as symbolic or material forms of freedom and domination. The prospect that both could be produced simultaneously from ambivalent characteristics of the same work practices, however, puts such discussions into question. Poised between capital and labour, between the sense of empowerment and the feeling of being objectified, middle managers do not neatly fit into the commonly-accepted labour process narrative.

Our study witnessed auditing experts experiencing de-skilling regarding their auditing and accounting knowledge due to the competing demands placed upon them by their mediational responsibilities. In contrast to the more well-documented concerns regarding the mechanization and standardization of labour (Braverman, 1974), here alienation results from work being stretched across multiple situations, creating myriad demands and a resultant loss of bearings. Although these aspects require further study, a tentative suggestion would be that managerial or professional alienation may involve deskilling, but also detachment from important social and professional sources of identification, rather than the more classical treatments of alienation from the means and products of labour.

At the same time, as boundary subjects, middle managers experienced mastery in their interfacing between different organizational ranks and areas (Huy, 2001), spanning diverse logics (Llewellyn, 2001) and divergent coalitions (Raes et al., 2011). This shift from traditional expertise to the 'translational' role of mediation involved a kind of reflexive practice that was experienced as emancipatory. We contribute to existing understandings of workplace emancipation by suggesting that the erosion of role positions may leave in its 
place new forms of practice that are destabilizing yet open, combining the reflexivity needed to navigate divergent positions with the anxiety of de-professionalization.

Studies in the "micro-emancipation" tradition (Alvesson and Willmott, 1992) have conceptualized everyday transgressions as potentially emancipatory (e.g. Courpasson, 2017). While remaining agnostic on the objective power of boundary work to change organizations or to resist formal structures, our study adds the important caveat that work activities that fulfill actual organizational responsibilities embody deeply taxing, unstable and demanding work systems even as they may be experienced as emancipatory. This contribution opens up our empirical and conceptual gaze to a range of possible experiences of work and questions their relationship to objective work conditions.

The lack of closeness among managers in our study was notable; with few exceptions, managers did not rely on peers to accomplish work, and did not see or refer to themselves as forming a particular organizational group. When not in the presence of their coworkers, our managers seemed to occupy a non-populated "backstage" (Goffman, 1959), a deserted space, contrasting with the observed exuberance of their social interactions. Relegated to their subjective state of reflexive vigilance and unable to identify with professional peers, they could not share this backstage with their coworkers, nor even with other middle managers, who might seem to be their natural companions there. This lonely backstage, then, can be understood as a side-effect of instrumentalized coworker relations and rivalry in relation to peers. Furthermore, habits such as exchanging best practices and mutual counseling were not observed or reported. In this sense, the subjective experience of emancipation as individual freedom contrasted notably with critical theoretical notions of emancipation as objective and rooted in social solidarity (e.g. Dean, 2012). Thus, our study contributes to the literature on alienation by arguing that diverse roles and professional relationships may lead individuals to a dearth of deep personal ties and of meaningful belonging to organizational groups. 


\subsection{Contributions to Managerial Work Literature}

Our study strives to achieve a better understanding of managerial work by introducing the concept of the boundary subject to account for middle managers' experience of boundary work. We challenge the assumption that managerial work aims at consensus and that its precariousness and contradictions provoke only distress, proposing dual explanations that add complexity to current understandings of managerial work.

Conceptualizing middle managers as boundary subjects engaging in boundary work, we extend the analytical reach of the boundary subject concept (Huzzard et al., 2010). Corroborating prior claims that individuals can perform boundary object functions (Huzzard et al., 2010; Laine et al., 2016), we go beyond a focus on how employees link heterogeneous groups. Rather, we explore the experiential aspects of middle managers' status as boundary subjects. Thus, this paper expands the concept of the boundary subject to account for the lived experiences triggered by boundary work.

More broadly, our theorization links to discussions surrounding hybridity, multiplicity and the ambivalent workplace experiences they imply - for instance, in studies of interorganizational collaborations (Teulier and Rouleau, 2013) or of the power-identity struggles within hybrid organizations (e.g. Mangen and Brivot, 2015). Individuals working in such inbetween circumstances may experience switching between multiple roles as being important parts of their interfacing job. Thus, the expanded concept of boundary subjects is important where such interface conditions shape individuals' lived experience.

Middle managers' positions as boundary subjects are malleable and constructed through and in social relations (Down and Reveley, 2009) between diverse groups (Clarke et al., 2009). Most studies characterize this social plasticity primarily as a source of struggle and distress (e.g. Harding et al., 2014; Sims, 2003; Thomas and Linstead, 2002). Conversely, at the site of our analysis, the intermediation of fragile functional and political arrangements 
also allowed middle managers to feel liberated because "it is in moments of dissensus and disagreement where the experience and moment of emancipation is to be found" (Huault et al., 2012: 12). Echoing Ekman's (2014) work on the opportunism made possible by precarious situations, it was exactly the precarious and contradictory nature of middle managerial boundary work, deployed in the interstices of relations, interpretation and interests, that offered possibilities for emancipatory experiences. This experience was felt in the heightened reflexivity of those inhabiting in-between positions (Turner, 1969). In short, boundary subjects simultaneously represented experiences of emancipation and alienation, and the associated reflexivity reflected both a loss of authentic presence at work and the ability to change perspectives while stepping outside given positions.

Our focus on differences across boundaries stands in contrast to the focus on the achievement of consensus in much existing literature on managerial work (e.g. Nielsen, 2009; Rouleau, 2005). We agree that middle managerial work crosses different organizational worlds, existing at the intersection of and translating between diverse dialogues (e.g. Balogun et al., 2005; Llewellyn, 2001). However, this cross-over function should not be understood as synonymous with achieving consensus: "consensus is not necessary for cooperation nor for the successful conduct of work" (Star and Griesemer, 1989: 388). Meanings and interests can be reconciled without their full convergence.

In the contemporary workplace, middle managers' lack of decision-making power leads them to spend time in discussions with subordinates to find solutions (Vie, 2010) and confront multifaceted responsibilities (Tengblad, 2012). While we corroborate the perpetual 'negotiational' aspects of contemporary middle managerial work, we add that these job aspects configure work to produce experiences of both emancipation and alienation. Thus, our two-sided view adds nuance to understanding middle managerial work and well-being.

\subsection{Future Research Directions, Limitations and Conclusion}


The implications of boundary work, and the heterogeneity of the lived experiences of boundary subjects positioned between constituencies, leaves several questions open for exploration. Our study adds to literature in which workplace uncertainty gives rise to ambivalent responses regarding the emancipatory potential inherent in the work role (Ekman, 2014; Endrissat et al., 2015; Sturdy et al., 2016). Complementing labour process perspectives that view workplace changes in relation to objective conditions, we have shown that similar external conditions can give rise to complex subjective experiences in which emancipation and alienation can co-emerge. Following Ekman's (2014) discussion of the hybrid and double-sided nature of flexibility in creative work, and Endrissat et al.'s (2015) focus on the ambiguities of worker emancipation in low-paid service work, critical scholarship must deal with the fact that workers experience freedom as well as constraint, characterizing their jobs as both vehicles for self-expression and sources of suffering. The next step in the research agenda is to theorize the objective conditions of worker alienation developed in labour process approaches together with the ambivalence of lived experience, moving beyond 'subjective' and 'objective' forms of workplace emancipation to understand the complex interaction between the two levels.

Notably, our focus on lived experience as a reflection of emancipation and alienation may provide a contrast to more "structural" explanations of managers' experience and action. For instance, our focus on boundary work complements perspectives on boundary spanning that are common in contemporary descriptions of work dynamics (cf. Okhuysen et al., 2013); such work often focuses on structural positions as determinants of identity and interpersonal relations (e.g. Richter et al., 2006). Within the critical theory tradition, moreover, emancipation and alienation are often explained through structural relations of class antagonism, rather than being treated at the level of worker experience as such (cf. Dickens, 1994). We support such structural explanations both at the level of networks and as a mode of 
critical theorizing about emancipation and alienation as social forces. Our approach is complementary to such traditions, providing responses to, and encouraging inquiry into, the question of how such structural positions and forces are experienced at the level of lived experience as actors enact and reflect such structures throughout their work.

In terms of context, our results should also be read in the light of the weak internal controls characteristic of Brazilian organizations, which could support the margin of action of middle managers. The strong emphasis on personalist ties and unstable systems that are characteristic of Brazilian management (cf. Islam, 2012) make our site a particularly wellsuited case for studying inter-group boundary work; conversely, settings with tighter internal control systems might allow less of a margin for such boundary work. To the extent, however, that organizational stability gives way to increasing "liquidity", such sites may proliferate and become prevalent even in advanced economies.

Our setting involved accountants and auditors performing managerial roles, a situation infused with politically charged and contested disciplinary practices (Covaleski et al., 1998). However, boundary work is likely prevalent across many different contexts. Czarniawska and Mazza (2003) and Sturdy et al. (2016) both noted the tactical use of liminality among knowledge workers. How other forms of workplace ambivalence result in respective experiences of emancipation and alienation is beyond the scope of this study; however, we would expect that non-professionalized work would encounter such ambivalence in other forms, especially given discussions of the deeply ambivalent experience of service work (e.g. Endrissat et al., 2015).

To conclude, middle managers' attempts to foster cross-functional collaboration force them to move into, out of and across a multitude of distinct organizational positions, rendering their work neither completely fluid nor stable. Our informants slipped between being autonomous reflexive subjects and passive objects caught in webs of motives that were 
not their own. Navigating between these conditions led them to experience both resourcefulness and aloofness in a tug-of-war between diverse demands. These experiences were key to the managers' social relations, in personal and intimate terms, and professional choices. In this way, experiencing both emancipation and alienation is a central and enduring feature of middle managerial work, and coping with this contradiction is a core aspect of working in, and inhabiting, middle managerial positions.

\section{REFERENCES}

Ahearne M, Lam S and Kraus F (2014) Performance impact of middle managers' adaptative strategy implementation: The role of social capital. Strategic Management Journal 35(1): 68-87.

Alvesson M and Willmott H (1992) On the idea of emancipation in management and organization studies. Academy of Management Review 17(3): 432-464.

Ashforth B, Kreiner G and Fugate M (2000) All in a day's work: Boundaries and micro role transitions. Academy of Management Review 25(3): 472-491.

Balogun J (2003) From blaming the middle to harnessing its potential: Creating change intermediaries. British Journal of Management 14(1): 69-83.

Balogun J, Gleadle P, Hailey V and Willmott H (2005) Managing change across boundaries: Boundary-shaking practices. British Journal of Management 16(4): 261-278.

Barley S and Kunda G (2001) Bringing work back in. Organization Science 12(1): 76-95. Beck T and Plowman D (2009) Experiencing rare and unusual events richly: The role of middle managers in animating and guiding organizational interpretation. Organization Science 20(5): 909-924.

Beech N (2011) Liminality and the practices of identity reconstruction. Human Relations 64(4): 285-302.

Blauner R (1964) The Factory Worker and His Industry. Chicago: U. of Chicago Press. 
Blumer H (1954) What is wrong with social theory? American Sociological Review 19: 14658.

Braverman H (1974) Labor and Monopoly Capital: The Degradation of Work in the Twentieth Century. New York: Monthly Review Press.

Bryant M and Stensaker I (2011) The competing roles of middle management: Negotiated order in the context of change. Journal of Change Management 11(3): 353-373.

Clarke C, Brown A and Hailey V (2009) Working identities? Antagonistic discursive resources and managerial identity. Human Relations 62(3): 323-352.

Clegg S (1989) Radical revisions: Power, discipline and organizations. Organization Studies 10(1): 97-115.

Corbin J and Strauss A (2008) Basics of Qualitative Research: Techniques and Procedures for Developing Grounded Theory. Los Angeles: Sage.

Costas J and Fleming P (2009) Beyond dis-identification: A discursive approach to selfalienation in contemporary organizations. Human Relations 62(3): 353-378.

Courpasson D (2017) The politics of everyday. Organization Studies 38(6): 843-859.

Courpasson D and Vallas S (2016) Resistance Studies: A critical introduction. In: Courpasson D and Vallas S (eds) The Sage Handbook of Resistance. London: Sage.

Covaleski M, Dirsmith M, Heian J and Samuel S (1998) The calculated and the avowed: Techniques of discipline and struggles over identity in Big Six public accounting firms. Administrative Science Quarterly 43(2): 293-327.

Czarniawska B and Mazza C (2003) Consulting as a liminal space. Human Relations 56(3): 267-290.

Dean J (2012) The Communist Horizon. London: Verso.

Delmestri G and Walgenbach P (2005) Mastering techniques or brokering knowledge?Middle managers in Germany, Great Britain and Italy. Organization Studies 26(2): 197-220. 
Dickens P (1997) Reconstructing nature: Alienation, emancipation and the division of labour. London: Routledge.

Down S and Reveley J (2009) Between narration and interaction: Situating first-line supervisor identity work. Human Relations 62(3): 379-401.

Ekman S (2014) Is the high-involvement worker precarious or opportunistic? Hierarchical ambiguities in late capitalism. Organization 21(2): 141-158.

Endrissat N, Islam G and Noppeney C (2015) Enchanting work. New spirits of service work in an organic supermarket. Organization Studies 36(11): 1555-1576.

Fayol H (1916/1979). Administration Industrielle et Générale (Functions and Principles of Management). Bulletin de la Société de l'Industrie Minérale. Paris: Dunod.

Geertz C (1973) The Interpretation of Cultures. New York: Basic Books.

Goffman E (1959) The Presentation of Self in Everyday Life. New York: Anchor Books.

Harding N, Lee H and Ford J (2014) Who is 'the middle manager'? Human Relations 67(10): $1213-1237$.

Hodson R (1996) Dignity in the workplace under participative management: Alienation and freedom revisited. American Sociological Review 61(5): 719-738.

Huault I, Perret V and Spicer A (2014) Beyond macro- and micro- emancipation: Rethinking emancipation in organization studies. Organization 21(1): 22-49.

Huy Q (2001) In praise of middle managers. Harvard Business Review 79: 72-79.

Huzzard T, Ahlberg B and Ekman M (2010) Constructing interorganizational collaboration: The action researcher as boundary subject. Action Research 8(3): 293-314.

Islam G (2012) Between unity and diversity: Historical and cultural foundations of Brazilian management. European Journal of International Management 6(3): 265-282.

Järventie-Thesleff R and Tienari J (2016) Roles as mediators in identity work. Organization Studies 37(2): 237-265. 
Keys B and Bell R (1982) Four faces of the fully functioning middle manager. California Management Review 24(4): 59-67.

Korica M, Nicolini D and Johnson B (2017) In search of 'managerial work: Past, present and future of an analytical category. International Journal of Management Reviews 19(2): $151-174$.

Kornberger M, Justesen L and Mouritsen J (2011) "When you make manager, we put a big mountain in front of you": An ethnography of managers in a Big 4 Accounting Firm. Accounting, Organizations and Society 36(8): 514-533.

Laclau, E (1996) Emancipation(s). London: Verso.

Laine T, Korhonen T, Suomala P and Rantamaa A (2016) Boundary subjects and boundary objects in accounting fact construction and communication. Qualitative Research in Accounting \& Management 13(3): 303-329.

Lamont M and Molnár V (2002) The study of boundaries in the social sciences. Annual Review of Sociology (28): 167-95.

Llewellyn S (2001) Two-way windows: Clinicians as medical managers. Organization Studies 22(4): 593-623.

Mair J and Thurner C (2008) Going global: How middle managers approach the process in medium-sized firms. Strategic Change 17(3/4): 83-99.

Mangen C and Brivot M (2015) The challenge of sustaining organizational hybridity: The role of power and agency. Human Relations 68(4): 659-684.

Mantere S (2008) Role expectations and middle manager strategic agency. Journal of Management Studies 45(2): 294-316.

Marx K (1844/1988). Economic and Philosophic Manuscripts of 1844. New York: Prometheus Books.

Mintzberg H (1973) The Nature of Managerial Work. New York: Harper \& Row. 
Mintzberg H (1990) The manager's job: Folklore and fact. Harvard Business Review March/April: 163-176.

Mumby D, Thomas R, Martí I and Seidl D (2017) Resistance redux. Organization Studies 38(9): 1157-1183.

Nielsen M (2009) Interpretative management in business meetings. Journal of Business Communication 46(1): 23-56.

Okhuysen G, Lepak D, Ashcraft K., Labianca G, Smith V and Steensma, H (2013) Theories of work and working today. Academy of Management Review 38(4): 491-502.

Pappas J and Wooldbridge B (2007) Middle manager's divergent strategic activity: An investigation of multiple measures of network centrality. Journal of Management Studies 44(3): 323-341.

Pawlowski S and Robey D (2004) Bridging user organizations: Knowledge brokering and the work of information technology professionals. MIS Quarterly 28(4): 645-672.

Peschanski V (1985) Middle managers in contemporary capitalism. Acta Sociologica 28(3): $243-255$.

Prasad P and Prasad A (2000) Stretching the iron cage: The constitution and implications of routine workplace resistance. Organization Science 11(4): 387-403.

Raes A, Heijltjes M, Glunk U and Roe R (2011) The interface of the top management team and middle managers: A process model. Academy of Management Review 36(1): 102126.

Richter A, West M, van Dick R and Dawson J (2006) Boundary spanners' identification, intergroup contact, and effective intergroup relations. Academy of Management Journal 49: $1252-1269$. 
Rouleau L (2005) Micro-practices of strategic sensemaking and sensegiving: How middle managers interpret and sell change every day. Journal of Management Studies 42(7): $1413-1441$.

Rouleau L and Balogun J (2011) Middle managers, strategic sensemaking, and discursive competence. Journal of Management Studies 48(5): 953-983.

Schacht R (1970) Alienation. Garden City, NY: Anchor Books.

Sillince J and Mueller F (2007) Switching strategic perspective: The reframing of accounts of responsibility. Organization Studies 28(2): 155-176.

Sims D (2003) Between the millstones: A narrative account of the vulnerability of middle managers' storying. Human Relations 56(10): 1195-1211.

Simpson B and Carroll B (2008) Re-viewing "role" in processes of identity construction. Organization 15: 29-50.

Star S (1989) Regions of the Mind: Brain Research and the Quest for Scientific Certainty. Stanford: Stanford University Press.

Star S and Griesemer J (1989) Institutional ecology, translations and boundary objects: Amateurs and professionals in Berkeley's museum of vertebrate zoology, 1907-39. Social Studies of Science 19(3): 387-420.

Sturdy A, Wright C and Wylie N (2016). Managers as consultants: The hybridity and tensions of neo-bureaucratic management. Organization 23(2): 184-205.

Sveningsson S and Alvesson M (2003) Managing managerial identities: Organizational fragmentation, discourse and identity struggle. Human Relations 56(10): 1163-1193. Tengblad S (2012) Management in Practice: Overview of Classic Studies on Managerial Work. New York: Oxford University Press. 
Teulier R and Rouleau L (2013) Middle managers' sensemaking and interorganizational change initiation: Translation spaces and editing practices. Journal of Change Management 13(3): 308-337.

Thomas R and Linstead A (2002) Losing the plot? Middle managers and identity. Organization 9(1): 71-93.

Turnbull S (2001) Corporate ideology: Meanings and contradictions for middle managers. British Journal of Management 12(3): 231-242.

Turner V (1969) The Ritual Process: Structure and Anti-Structure. Chicago: Aldine de Gruyter.

Van Maanen J (1998) Qualitative Studies of Organizations. Thousand Oaks: Sage.

Vie O (2010) Have post-bureaucratic changes occurred in managerial work? European Management Journal 28(3): 182-194.

Watson T (1995) Rhetoric and argument in organizational sense making: A reflexive tale. Organization Studies 16(5): 805-821.

Watson T (2011) Ethnography, reality, and truth: The vital need for studies of 'how things work' in organizations and management. Journal of Management Studies 48(1): 202-17.

Wooldridge B, Schmid T and Floyd S (2008) The middle management perspective on strategy process: Contributions, synthesis, and future research. Journal of Management 34(6): 1190-1221. 
Table 1. BRABIG's personnel structure

\begin{tabular}{|l|c|c|c|c|c|c|c|c|}
\hline \multicolumn{1}{|c|}{ Groups / Locations $^{5}$} & HQ-RS & SP & RJ & PR & DF & USA & Total & \% \\
\hline Top management & 3 & 0 & 0 & 0 & 0 & 1 & 4 & $\mathbf{2 \%}$ \\
\hline Middle management & 10 & 6 & 2 & 1 & 1 & 0 & 20 & $\mathbf{9 \%}$ \\
\hline Auditors \& consultants & 75 & 30 & 20 & 13 & 8 & 0 & 146 & $\mathbf{6 5 \%}$ \\
\hline Back-office & 40 & 10 & 2 & 2 & 1 & 0 & 55 & $\mathbf{2 4 \%}$ \\
\hline Total & $\mathbf{1 2 8}$ & $\mathbf{4 6}$ & $\mathbf{2 4}$ & $\mathbf{1 6}$ & $\mathbf{1 0}$ & $\mathbf{1}$ & $\mathbf{2 2 5}$ & $\mathbf{1 0 0 \%}$ \\
\hline \% of company total & $\mathbf{5 7 \%}$ & $\mathbf{2 0 \%}$ & $\mathbf{1 1 \%}$ & $\mathbf{7 \%}$ & $\mathbf{5 \%}$ & $\mathbf{0 \%}$ & $\mathbf{1 0 0 \%}$ & \\
\hline
\end{tabular}

${ }^{5}$ HQ-RS: Headquarters, in Rio Grande do Sul (southern Brazil). SP: Branch in São Paulo (1,100 km from HQ). RJ: Branch in Rio de Janeiro (1,550 km from HQ). PR: Branch in Paraná (700 km from HQ). DF: Branch in the Federal District - Brasília (2,100 km from HQ). 
Table 2. Profile of the Middle Managers Who Were Interviewed Recurrently

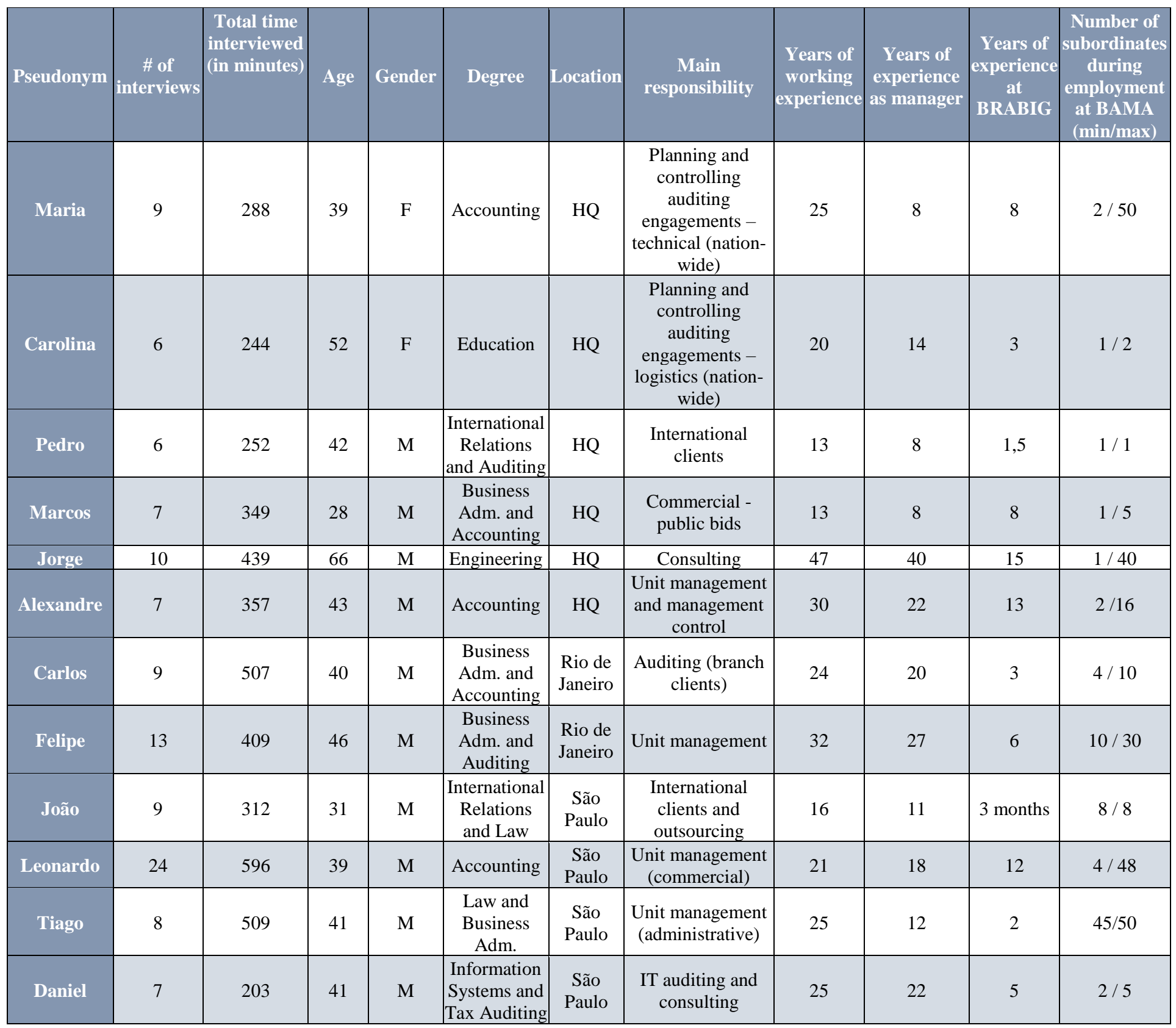


Table 3. Overview of Data Structure
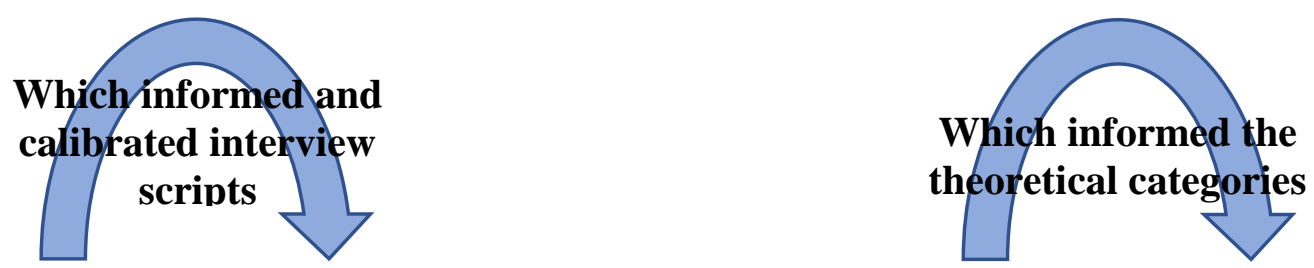

\begin{tabular}{|c|c|c|}
\hline $\begin{array}{c}\text { Illustrative Codes from } \\
\text { Observations and Shadowing Field } \\
\text { Notes } \\
\text { (regarding boundary work) }\end{array}$ & $\begin{array}{l}\text { Illustrative Extracts from Interviews } \\
\text { (regarding the experiences of boundary work) }\end{array}$ & $\begin{array}{l}\text { Aggregate } \\
\text { Theoretical } \\
\text { Dimensions }\end{array}$ \\
\hline $\begin{array}{l}\text { Performing several roles (e.g. } \\
\text { director, auditing partner, auditor, } \\
\text { consultant, salesperson and } \\
\text { organizational psychologist). } \\
\text { Purposefully changing attitudes and } \\
\text { behaviors depending on role and } \\
\text { situation. } \\
\text { Expressing a feeling of mastering } \\
\text { multiplicity and of playing a game. } \\
\text { Knowledge about groups' } \\
\text { differences. } \\
\text { Expressing feelings of } \\
\text { capability/professional asset. } \\
\text { Delegation from top management to } \\
\text { deal with different actors in different } \\
\text { fronts. }\end{array}$ & $\begin{array}{l}\text { I am multi-functional. (Alexandre) } \\
\text { You deal with multiple fronts, multiple segments, } \\
\text { multiple markets, various types of clients and } \\
\text { various situations. (Jorge) } \\
\text { Depending on the situation you have to be more or } \\
\text { less formal, sometimes you have to use and abuse } \\
\text { technical terms to gain respect, but it is not everyone } \\
\text { who is able to do that. (Carlos) }\end{array}$ & Mastery \\
\hline $\begin{array}{l}\text { Expressing sense of increased } \\
\text { freedom and leeway. } \\
\text { Demonstrating feeling of ability to go } \\
\text { beyond a single function. } \\
\text { Sense of not being limited by one's } \\
\text { roles and positions. } \\
\text { Describing oneself as more than } \\
\text { one's specific job. }\end{array}$ & $\begin{array}{l}\text { [My work] involves the entire structure of the } \\
\text { company, mainly in the commercial matters. } \\
\text { Because the commercial area interacts with the } \\
\text { financial area, with the technical area, with the after- } \\
\text { sales, with the other offices, and with the directors. } \\
\text { Then I'm going to explode to all [areas], and up and } \\
\text { down [in the hierarchy]. (João) } \\
\text { Regardless of the level, if the company has a } \\
\text { problem, I cannot wash my hands and say "that's not } \\
\text { my problem!". (Felipe) }\end{array}$ & Autonomy \\
\hline $\begin{array}{l}\text { Introducing themselves as directors } \\
\text { rather than managers. } \\
\text { Getting involved with strategic } \\
\text { matters without requiring directors }\end{array}$ & $\begin{array}{l}\text { I am the spokesperson of the headquarters. (Felipe) } \\
\text { As a director at that moment, I may commit myself } \\
\text { to some things that the top management would agree } \\
\text { with. So my knowledge of them [top managers] is }\end{array}$ & $\begin{array}{c}\text { Empowerme } \\
\text { nt }\end{array}$ \\
\hline
\end{tabular}


consent.

Attending clients' meetings where only clients' directors are present.

Doubtful about the latitude of their action spheres.

Questioning the scope of their possibilities and responsibilities.

Doubtful about "caps" on how far they can compromise firms' liability and resources.

Difficulties in dealing with multiple groups simultaneously.

Enduring the accumulation of roles.

Confusion about evolving ways of addressing themselves.

Particular situations cause more distress in changing and adjusting attitudes and behaviors.

Lack of drive regarding how to behave.

Sense of going with the flow rather than being in control of their agenda, behavior and pursuits.

Perception of re-acting rather than acting.

Sense of not being updated about accounting, auditing and taxation matters.

Too busy to review technical (auditing) matters. very important. At the time I have to think what would they [directors] do?...I strive to know their positioning on various subjects... and this will help me to be [play the role of] director, because if I do not play the director with the client, most often I do not have [keep] the client. (Leonardo)

The truth is that there is a responsibility greater than the function... Then there are problems that are not from your area, but if you're just there, you will solve them. (Alexandre)

Strange that it's necessary, but no one told me during my MBA. It is almost like being an actor, without being false, but it's a representation. I have to be a chameleon to make myself understood. (Tiago)

I am putting myself on equal footing to discuss some situations compared to the Technical Director's footing. So there is a mixture [overlaps]. There is no clear role on that. Although it is clear that he is the Technical Director. (Leonardo)

You have to be diplomatic. You have to please both the Greeks and the Trojans. (João)

Sometimes you're being pushed by the boss and also by the subordinates, about the same thing at the same time, real-time on the phone, and you need to hold onto yourself to both hear the demand being made and at the same time transform yourself to speak to the one implementing it. (Tiago)

You are accountable for things over which you have no control. (Felipe)

You have to pay attention, to be aware that sometimes you're an actor but you do not direct the action. (Leonardo)

I have to know how to work with people from other sectors. I have to be flexible, seek to understand people, not only those of my sector but also those from other sectors. (Carolina)

After closing the sale, it is difficult to change the client's focal point in the firm. The clients will be
Lack of selfdeterminati on

Reflexivity

Fatigue

Detachment

from profession 


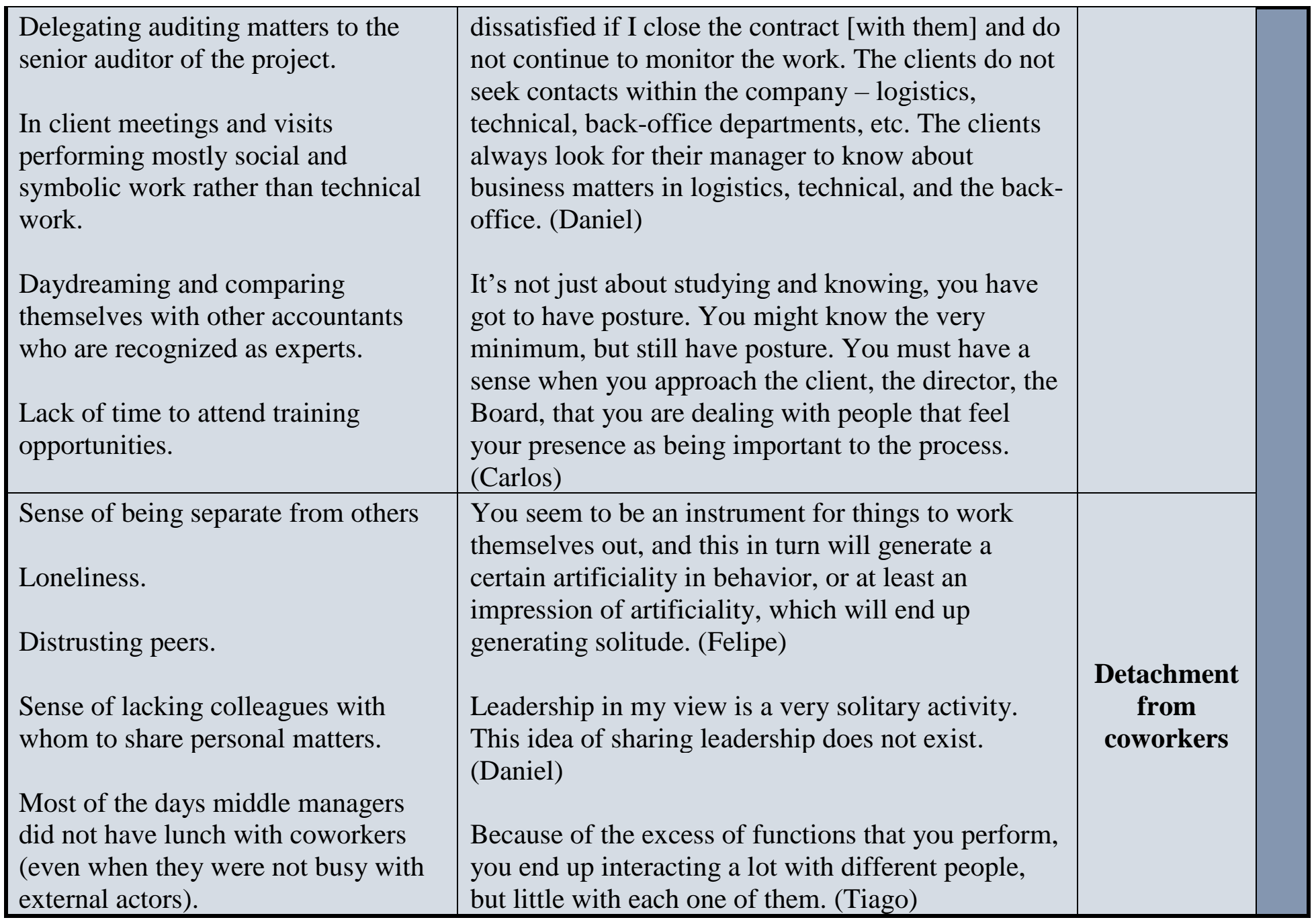

